\title{
Somatostatin Receptors Subtypes 2 and 5, Dopamine Receptor Type 2 Expression and gsp Status as Predictors of Octreotide LAR $^{\circledR}$ Responsiveness in Acromegaly
}

\author{
clinical case report
}

\section{LEONARDo VieIRA Neto \\ Giselle Fernandes TABOADA \\ MôNica Roberto GadelHa}

Endocrinology Unit - Hospital Universitário Clementino Fraga Filho/Universidade Federal do Rio de Janeiro (LVN, GFT, MRG);

Endocrinology Unit - Instituto Estadual de Diabetes e Endocrinologia Luiz Capriglione do Rio de Janeiro (IEDE) (MRG); Rio de Janeiro, RJ, Brazil.

Received in 25/8/2008

Accepted in 14/10/2008
We present two acromegalic patients in which clinical and molecular data are discussed in regard to their ability to predict long term octreotide LAR ${ }^{\circledR}$ therapy response. Case reports: Patient 1: female, 36 years old at diagnosis. Basal GH and IGF-I at diagnosis were $133 \mathrm{ng} / \mathrm{mL}$ and $181 \%$ above the upper limit of reference values (ULRV), respectively. Growth hormone during acute test with subcutaneous octreotide decreased from 133 to $13 \mathrm{ng} / \mathrm{mL}$. Patient started on primary octreotide $L A R^{\circledast}$ therapy (20mg q28 days) and achieved biochemical parameters of disease control after 6 months. Molecular analysis of tumor fragments: gsp +; quantitative analysis of SSTR (somatostatin receptor) and DR (dopamine receptor) mRNA - SSTR2 23954; SSTR5 2407; DR2 total 17016 copies. Patient 2: male, 38 years old at diagnosis. Basal GH and IGF-I at diagnosis were $120 \mathrm{ng} / \mathrm{mL}$ and $114 \%$ ULRV, respectively. Patient underwent noncurative trans-sphenoidal surgery. Post-operative GH and IGF-I were $112 \mathrm{ng} /$ $\mathrm{mL}$ and $137 \%$ ULRV, respectively. Growth hormone during acute test with subcutaneous octreotide decreased from 112 to $7 \mathrm{ng} / \mathrm{mL}$. Octreotide LAR ${ }^{\circledast}$ therapy (20 mg q28 days) was then initiated. After 6 months of treatment, patient did not attain biochemical control of disease and displayed increased tumor volume. Molecular analysis of tumor fragments: $g s p$ not done; quantitative analysis of SSTR and DR mRNA - SSTR2 416; SSTR5 3767; DR2 total 3439 copies. In conclusion, these two cases illustrate how laboratory data can be conflicting as predictors of octreotide $L R^{\circledR}$ responsiveness and how molecular analysis of tumor fragments can help explain different behaviors in clinically similar patients. (Arq Bras Endocrinol Metab 2008; 52/8:1288-1295)

Keywords: Acromegaly; Somatostatin receptor; Dopamine receptor; Octreotide $L A R^{\circledR}$.

\section{RESUMO}

Expressão dos Receptores da Somatostatina Subtipos 2 e 5 e do Receptor da Dopamina tipo 2 e gsp Status como Preditores de Resposta ao Octreotide LAR $^{\circledR}$ na Acromegalia.

Apresentamos dois pacientes acromegálicos nos quais dados clínicos e moleculares são discutidos quanto à sua capacidade de predizer a resposta a longo prazo ao tratamento com octreotide LAR $^{\circledR}$. Relato dos casos: Paciente 1: Feminina, 36 anos de idade ao diagnóstico. GH e IGF-I ao diagnóstico 133 $\mathrm{ng} / \mathrm{mL}$ e $181 \%$ acima do limite superior do valor de referência (LSVR), respectivamente. GH durante o teste agudo com octreotide subcutâneo diminuiu de 133 para $13 \mathrm{ng} / \mathrm{mL}$. Foi iniciado tratamento primário com octreotide LAR $^{\circledR}$ (20 mg q28 dias) e a paciente alcançou os parâmetros bioquímicos de controle de doença depois de seis meses. Análise molecular do tumor: $g s p+$; análise quantitativa do mRNA de SSTR (receptores de somatostatina) e DR (receptor de dopamina) - SSTR2 23.954; SSTR5 2.407; DR2 total 17.016 cópias. Paciente 2: Masculino, 38 anos de idade ao diagnóstico. GH e IGF-I ao diagnóstico $120 \mathrm{ng} / \mathrm{mL}$ e 114\% LSVR, respectivamente. Paciente foi sub- 
metido à cirurgia trans-esfenoidal não-curativa. GH e IGF-I pós-operatórios $112 \mathrm{ng} / \mathrm{mL}$ e $137 \%$ LSVR, respectivamente. GH durante o teste agudo diminuiu de 112 para $7 \mathrm{ng} / \mathrm{mL}$. Foi iniciado tratamento com octreotide LAR $^{\circledR}$ (20 mg q28 dias). Após seis meses o paciente não alcançou controle bioquímico e apresentou aumento do volume tumoral. Análise molecular do tumor: gsp não estudado; análise quantitativa do mRNA de SSTR e DR SSTR2 416; SSTR5 3.767; DR2 total 3.439 cópias. Em conclusão, estes dois casos ilustram como dados laboratoriais podem ser conflitantes enquanto preditores de resposta ao tratamento com octreotide $L A R^{\circledR}$ e como a análise molecular de fragmentos do tumor pode ajudar a explicar comportamentos diferentes em pacientes clinicamente semelhantes. (Arq Bras Endocrinol Metab 2008; 52/8:1288-1295)

Descritores: Acromegalia; Receptor de somatostatina;Receptor de dopamina; Octreotide LAR ${ }^{\circledR}$.

\section{INTRODUCTION}

T rans-sphenoidal surgery is the most common initial treatment approach of patients with somatotropinomas (1). However, somatotropinomas are more often expansive macroadenomas and surgery is usually not curative. Surgical "cure" is correlated to the magnitude of initial GH levels, tumor size and invasiveness. The best results are achieved in microadenomas and macroadenomas restricted to the sella turcica, in which cure rates are around 75\%. Regarding the more invasive macroadenomas, the cure rates drop to $33-44 \%$ depending on the invasion magnitude (2).

Because surgery alone is frequently not curative, further treatment is often required. Somatostatin ana$\operatorname{logs}(\mathrm{SA})$ are a cornerstone of medical therapy for acromegaly. Octreotide LAR ${ }^{\circledR}$ therapy achieve 'safe' growth hormone $(\mathrm{GH})$ levels $(<2.5 \mathrm{ng} / \mathrm{mL})$ in $48-57 \%$ and insulin-like growth factor type I (IGF-I) normalization in $47-67 \%$ of the patients (3). Additionally, tumor shrinkage of at least $20 \%$ of the initial tumor volume occurs in $75 \%$ of the patients (4).

A main issue in medical therapy of acromegaly is the elevated cost. Considering that 'safe' GH levels and IGF-I normalization are not achieved in one third of the patients, it is useful to predict which patient is more likely to respond to SA. Several clinical, biochemical and molecular data have been evaluated for that purpose.

Several predictors of SA therapy efficacy have been studied. Pre-treatment GH level appear to be wellestablished as a negative predictor of achieving SA- mediated disease control (5). Also, attaining GH levels below $5 \mathrm{ng} / \mathrm{mL}$ after 3 months and IGF-I levels below $550 \mathrm{ng} / \mathrm{mL}$ after 6 months of SA treatment appear to be good positive predictors of long term control (6). GH suppression test, following a single subcutaneous injection of octreotide (acute test), has been extensively studied with variable results (7-14). Scintilography with 111 In-pentetreotide (Octreoscan) has also been studied, with limited success at predicting SA-mediated disease control $(8,15,16)$. Patients bearing densely granulated somatotropinomas on electron microscopy respond better to SA therapy than patients with sparsely granulated tumors (17). Immunohistochemical detection of somatostatin receptor subtype 2 (SSTR2) correlates positively with percent GH reduction on acute test and IGF-I after 6 months of treatment $(18,19)$. When molecular analysis of the ressected tumor is possible, the presence of the gsp oncogene seems to be indicative of a good response to SA treatment (20-26). Despite the fact that most studies suggest that gsp-positive adenomas respond better to octreotide $\mathrm{LAR}^{\circledast}$ compared to $g s p$-negative tumors, a recent study failed to find differences in octreotide $\mathrm{LAR}^{\circledR}$ sensitivity according to $g s p$ status (18). In addition, expression profiles of the mRNA somatostatin receptor subtypes (SSTR) in tumor fragments may serve as a predictive tool of biochemical and tumor volume response to SA therapy (24,27-32).

In this papers we present two patients in which clinical and molecular data are discussed in regard to their ability to predict long term SA therapy response. 


\section{SUBJECTS AND METHODS}

\section{Acute test with subcutaneous octreotide}

Octreotide - $100 \mathrm{mcg}$ - was administered subcutaneously and blood samples were drawn for GH measurements before and two hours after administration of the drug. A positive $\mathrm{GH}$ response in this test was defined as $>75 \%$ decrease of the GH levels. Sensitivity, specificity, positive and negative predictive values of the acute test were respectively $0.90,0.60,0.69$ and 0.86 for a reduction of $75 \%$ of the $\mathrm{GH}$ on the test (14).

\section{Growth hormone and IGF-I assays}

Growth hormone was assayed by chemoluminescence (Diagnostic Products Corporation, Los Angeles, CA) with an IMMULITE 1000 analyser. The detection limit of the assay is $0.01 \mu \mathrm{g} / \mathrm{L}(0.026 \mathrm{mU} / \mathrm{L})$. Inter and intra-assay coefficients of variation were $6.2 \%$ and $6.5 \%$, respectively. The assay detects the $22 \mathrm{KDa}$ isoform. The IRP (International Reference Preparation) used is $98 / 574$.

Insulin-like growth factor-I was assayed by IRMA after ethanol extraction of binding proteins (Diagnostic Systems Laboratories, Webster, TX). The detection limit of the assay is $0.80 \mu \mathrm{g} / \mathrm{L}$. Inter-assay coefficients of variation were $8.2 \%, 1.5 \%$ and $3.7 \%$ for the low, medium and high levels of the standard curve, respectively. Intraassay coefficients of variation were $3.4 \%, 3.0 \%$ and $1.5 \%$ for the low, medium and high levels of the standard curve, respectively. Results were expressed as the percent above the upper limit of the reference value (\%ULRV).

\section{Tumor volume assessment}

Magnetic resonance imaging (MRI) of the sella turcica was performed before and after 6 months of treatment with OCT $\mathrm{LAR}^{\circledR}$ on a clinical $1.5 \mathrm{~T}$ scanner, using $\mathrm{Tl}$ weighted gradient recalled-echo, in the sagittal and coronal planes. When assessed post-operatively (patient \#2) it was performed 3 months after the procedure. The acquisitions were repeated before and after the administration of gadolinium. Tumor volume was calculated by the Di Chiro and Nelson formula: sagittal $x$ coronal $\mathrm{x}$ axial diameters $\mathrm{x} \pi / 6(33)$.

\section{Quantitative real-time RT-PCR (qrtRT-PCR) of DR and SSTR subtypes mRNA from tumor samples}

Total RNA was extracted from $30 \mathrm{mg}$ of tissue sample obtained during trans-sphenoidal surgery using the
RNeasy ${ }^{\circledR}$ Mini Kit (Qiagen, Valencia, CA). To avoid contamination by genomic DNA, the RNA samples were treated with RNase-free DNase Set (Qiagen), as specified in the manufacturer's protocol. Reversal transcription was done using l $\mu$ g of total RNA in a $20 \mu \mathrm{L}$ volume. Synthesis of first strand cDNA suitable for PCR amplification was done using Kit First Strand cDNA Synthesis ${ }^{\circledR}$ (Fermentas, Hanover, MD) with random hexamer primer $(0.2 \mu \mathrm{g} / \mu \mathrm{L})$ and the cDNA was treated with RNase $\mathrm{H}$, as specified in the manufacturer's protocol.

Primers sets for DR2 total, DR2 long isoform, SSTR2 and SSTR5 were selected using Primer 3 software with human genomic sequences as templates. Primer pairs (sense / anti-sense and Genbank accession number) used in PCR reactions were: DR2 total: cgagcatcctgaacttgtgtg / gcgttattgagtccgaagagg (NM_016574); DR2 long isoform (DR2L): ctcctccatcgtctccttct / cggtgcagagtttcatgtcc (NM_000795); SSTR2: ggcatgtttgactttgtggtg / gtctcattcagccgggattt (NM001050); SSTR5: ctggtgtttgcgggatgtt / gaagctctggcggaagttgt (NM001053).

One microliter aliquots of the resulting cDNA were amplified by real time PCR using the primers $(0.375$ $\mu \mathrm{L}$ ), mixed with iQ SYBR $®$ Green Supermix $12.5 \mu \mathrm{L}$. The iQ SYBR® Green Supermix magnesium chloride $(\mathrm{MgCl} 2)$ concentration is $6 \mathrm{mM}$ and the final concentration in the reaction was $3 \mathrm{mM}$. Thermal cycling profile consisted of a pre-incubation step at $95{ }^{\circ} \mathrm{C}$ for 10 min, followed by 35 cycles of denaturation $\left(95^{\circ} \mathrm{C}, 30\right.$ s), annealing $\left(61-64^{\circ} \mathrm{C}, 1 \mathrm{~min}\right)$ and extension $\left(72^{\circ} \mathrm{C}\right.$, 30 s). Total RNA samples that were not reverse transcribed were run to control for genomic and/or technical DNA contamination (background). It should be noted that a standard curve was run with each set of samples to estimate copy number. At the end of the amplification the final product was subjected to graded temperature dependent dissociation, to verify that only one product was amplified. The detection limit of the method is 10 copies.

To control for variations in the amount of sample and the RNA quality used in the RT reaction and the efficiency of the RT reaction, the expression level (copy number) of three commonly used housekeeping genes (glyceraldehyde-3-phosphate dehydrogenase - GAPDH, $\beta$-actin, hypoxanthine ribosyltransferase - HPRT) was determined for each sample. Primers sets were also selected using Primer 3 software with human genomic sequences as templates. Primer pairs (sense / anti-sense and Genbank accession number) used in PCR reactions were: 
GAPDH: aatcccatcaccatcttcca / aaatgagcccagccttc (NM002046); $\beta$-actin: actcttccagccttccttcct / cagtgatctccttctgcatcct (NM001101); HPRT: ctgaggatttggaaagggtgt / taatccagcaggtcagcaaag (BT019350). To determine if these genes were appropriate to use as internal controls, the stability of expression was calculated using the GeNorm 3.3 visual basic application for Microsoft Excel (http://medgen.ugent.be/ jvdesomp/genorm/) as previously developed and validated by Vandesompele et al. (34). This program calculates the average pairwise variation of a particular gene with all other control genes (M), allowing elimination of the worst scoring control genes and recalculation of new $M$ values for the remaining genes. $\mathrm{M}$ values < 1.5 are indicative of a "stable gene". The geometric means of copy numbers for the most stable genes are then used as a normalization factor (NF). In our study, these three house keeping genes showed to be "stable" (all values were < 1.5). Therefore the geometric means of the copy numbers for these three genes within each sample were used as a normalization factor (NF). Results were then reported as median (minimum-maximum) of receptor copy number minus background divided by $\mathrm{NF}$.

\section{Analysis of the presence of gsp oncogene}

Deoxyribonucleic acid (DNA) was extracted using QIAamp DNA MiniKit (Qiagen, Valencia, CA) according to the protocol for isolation from fresh tissue. Exons 8 and 9 (including codons 201 and 227, respectively) of the gsp gene were amplified by polymerase chain reaction (PCR) using oligonucleotide primers as

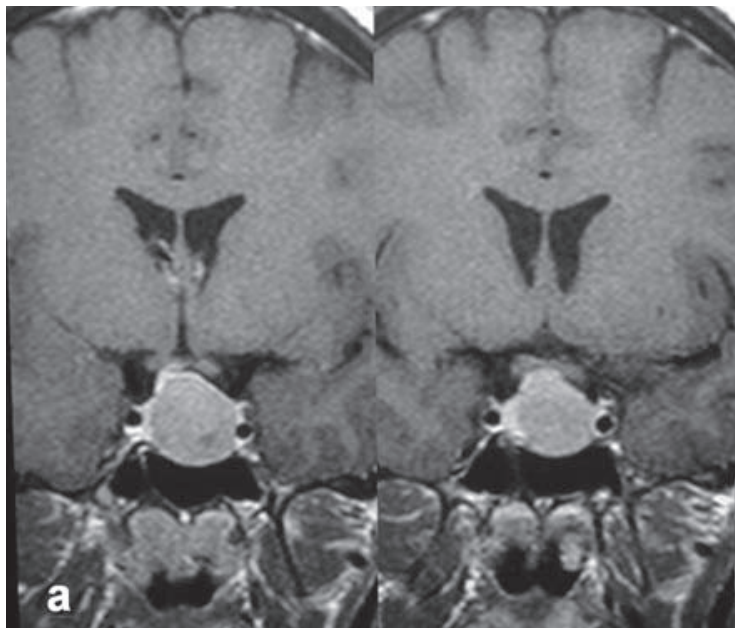

described previously (35). Each $50-\mu \mathrm{L}$ PCR reaction mix contained $2 \mu \mathrm{L}$ of DNA, 20 pmol of each primer and 5 units of DNA-Polymerase (TTH biotools; Biotools, Madrid, Spain). Thermal cycling profile consisted of a pre-incubation step at $95^{\circ} \mathrm{C}$ for $10 \mathrm{~min}$, followed by 40 cycles of denaturation $\left(95^{\circ} \mathrm{C}, 1 \mathrm{~min}\right)$, annealing $\left[56^{\circ} \mathrm{C}\right.$ (for codon 201 ) or $54^{\circ} \mathrm{C}$ (for codon 227 ), 1 min] and extension $\left(72^{\circ} \mathrm{C}, 1 \mathrm{~min}\right)$. The PCR products were then purified using the MinElute PCR Purification kit (Qiagen) and sequenced using the same oligonucleotide primers with an ABI3730XL analyzer (Applied Biosystems, Foster City, CA).

\section{CASE REPORTS}

Patient 1: Female, 36 years old at diagnosis, presented with classical signs and symptoms of acromegaly that was confirmed by lack of GH suppression to less than $1 \mathrm{ng} /$ $\mathrm{mL}$ on oral glucose tolerance test (OGTT) and elevated IGF-I for age. Basal GH and IGF-I at diagnosis were 133 $\mathrm{ng} / \mathrm{mL}$ and $181 \%$ ULRV, respectively. Sella turcica MRI revealed a macroadenoma with $4.73 \mathrm{~cm}^{3}$ (Figure 1A). Growth hormone during acute test with $100 \mathrm{mcg}$ subcutaneous octreotide decreased from 133 to $13 \mathrm{ng} / \mathrm{mL}$. Patient started on primary octreotide $\mathrm{LAR}^{\circledR}$ therapy (20 mg q28 days) as a part of a clinical research trial. After 3,6 and 12 months of octreotide $\operatorname{LAR}^{\circledR}$ therapy $(20 \mathrm{mg}$ q28 days), GH decreased to $5.2,1.7$ and $2.3 \mathrm{ng} / \mathrm{mL}$, respectively and IGF-I to 79,90 and $82 \%$ ULRV, respectively. Tumor volume decreased to 2.48 and $2.09 \mathrm{~cm}^{3}$ (Figure $1 B$ ) at 6 and 12 months (Table 1). Patient un-

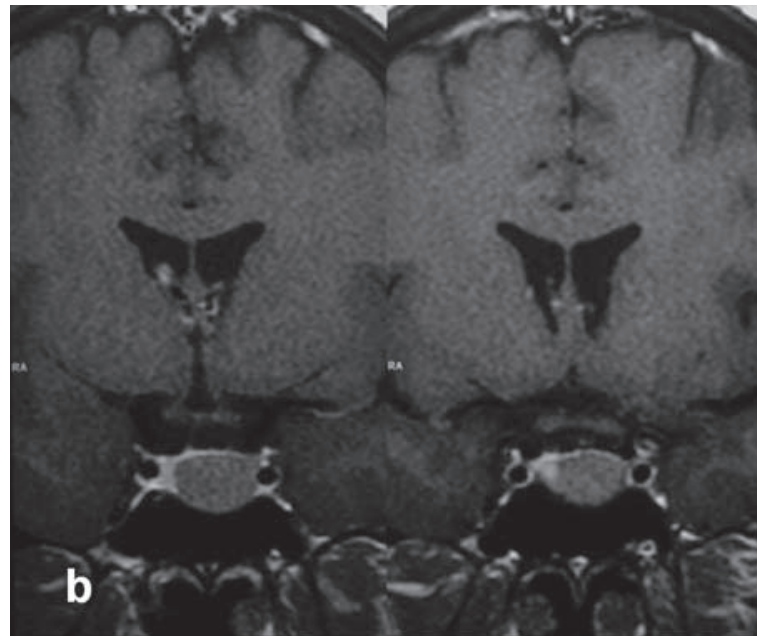

Figure 1. Sella turcica magnetic resonance, coronal view, T1 weighted, with contrast enhancement, before (a) (tumor volume $4.73 \mathrm{~cm}^{3}$ ) and 12 months after (b) (tumor volume $2.09 \mathrm{~cm}^{3}$ ) octreotide LAR $^{\circledR}$ treatment. 
derwent trans-sphenoidal surgery because of irregular supply of octreotide $\mathrm{LAR}^{\circledast}$ by the public health system. Molecular analysis of tumor fragments: gs $p+$; SSTR and DR mRNA expression - SSTR2 23954; SSTR5 2407; DR2 total 17016 copies (Table 2).

Patient 2: Male, 38 years old at diagnosis, was referred to our outpatient clinics for acromegaly treatment. Diagnosis was also supported by lack of GH suppression on OGTT and elevated IGF-I for his age. Basal GH and IGF-I at diagnosis were $120 \mathrm{ng} / \mathrm{mL}$ and $114 \%$ ULRV, respectively. Sella computed tomography showed a macroadenoma with $2.3 \times 1.8 \mathrm{~cm}$ with supra and left para-sellar extension. Patient underwent noncurative trans-sphenoidal surgery. Post-operative GH and IGF-I were $112 \mathrm{ng} / \mathrm{mL}$ and 137\% ULRV, respectively. Tumor volume on sella turcica MRI 3 months after surgery was $3.28 \mathrm{~cm}^{3}$ (Figure 2A). Growth hormone during acute test with subcutaneous octreotide decreased from 112 to $7 \mathrm{ng} / \mathrm{mL}$. Octreotide $\operatorname{LAR}^{\circledR}$ therapy (20mg q28 days) was then initiated. After 3 months of therapy, GH decreased to $13 \mathrm{ng} / \mathrm{mL}$, however after additional 3 months ( $30 \mathrm{mg}$ q 28 days) it increased to $30 \mathrm{ng} / \mathrm{mL}$. Insulin-like growth factor type I values were 293 and $290 \%$ ULRV, respectively. Tumor volume increased to $3.9 \mathrm{~cm}^{3}$ (Figure $2 \mathrm{~B}$ ) at 6 months of medical treatment (Table 1). Considering increased tumor volume and GH levels and unchanged IGF-I, a second surgical procedure was indicated. Post-operative GH and IGF-I were $19 \mathrm{ng} / \mathrm{mL}$ and 160\% ULRV, respectively. Molecular analysis of tumor fragments: gsp not done; SSTR and DR mRNA expression - SSTR2 416; SSTR5 3767; DR2 total 3439 copies (Table 2).

Table 1. Laboratory and imaging data in both patients.

\begin{tabular}{|c|c|c|c|c|c|c|c|c|c|c|c|c|c|}
\hline & \multicolumn{3}{|c|}{ Diagnosis } & \multicolumn{2}{|c|}{3 months } & \multicolumn{3}{|c|}{6 months } & \multicolumn{3}{|c|}{12 months } & \multicolumn{2}{|c|}{$\begin{array}{l}\text { Acute test } \\
\mathrm{GH}(\mathrm{ng} / \mathrm{mL})\end{array}$} \\
\hline & $\begin{array}{c}\text { GH (ng/ } \\
m L)\end{array}$ & $\begin{array}{c}\text { IGF-I } \\
\text { (\%ULRV) }\end{array}$ & $\begin{array}{c}\text { Tumor } \\
\text { volume } \\
\text { (cm3) }\end{array}$ & $\begin{array}{c}\mathrm{GH}(\mathrm{ng} / \\
\mathrm{mL})\end{array}$ & $\begin{array}{c}\text { IGF-I } \\
\text { (\%ULRV) }\end{array}$ & $\begin{array}{c}\mathrm{GH} \\
(\mathrm{ng} / \\
\mathrm{mL})\end{array}$ & $\begin{array}{c}\text { IGF-I } \\
(\% \text { ULRV) }\end{array}$ & $\begin{array}{c}\text { Tumor } \\
\text { volume } \\
\text { (cm3) }\end{array}$ & $\begin{array}{c}\text { GH } \\
(n g / \\
m L)\end{array}$ & $\begin{array}{c}\text { IGF-I } \\
(\% \text { ULRV) }\end{array}$ & $\begin{array}{c}\text { Tumor } \\
\text { volume } \\
\text { (cm3) }\end{array}$ & Basal & $2 \mathrm{~h}$ \\
\hline Patient 1 & 133 & 181 & 4.73 & 5.2 & 79 & 1.7 & 90 & 2.48 & 2.3 & 82 & 2.09 & 133 & 13 \\
\hline Patient 2 & $\begin{array}{c}120 \\
112 \dagger\end{array}$ & $\begin{array}{c}114 \\
137 \dagger\end{array}$ & $\begin{array}{c}\ddagger \\
3.28 \dagger\end{array}$ & 13 & 293 & 30 & 290 & 3.9 & ND & ND & ND & 112 & 7 \\
\hline
\end{tabular}

\%ULRV: percent above the upper limit of the reference value; † Post-operative data ( $1^{\text {st }}$ surgery); $\ddagger$ Tumor volume was not assessed at diagnosis because the patient presented with a sella computed tomography.
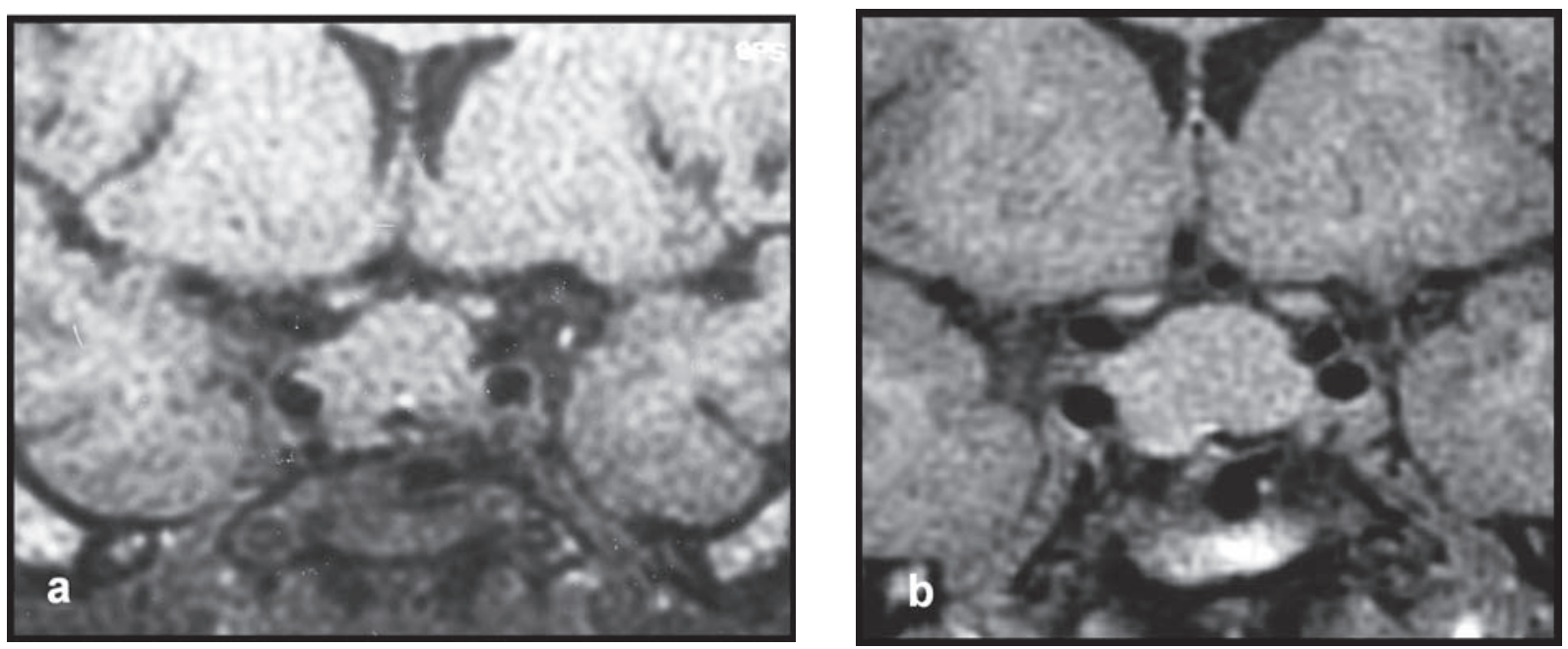

Figure 2. Sella turcica magnetic resonance, coronal view, Tl weighted, with contrast enhancement, before (A) (tumor volume $3.28 \mathrm{~cm}^{3}$ ) and 6 months after (B) (tumor volume $3.90 \mathrm{~cm}^{3}$ ) octreotide LAR ${ }^{\circledR}$ treatment. 
Table 2. Dopamine and somatostatin receptor subtypes mRNA expression (copy number corrected for normalization factor) and gsp oncogene in both patients.

\begin{tabular}{lcc}
\hline & Patient 1 & Patient 2 \\
\hline DR2 total / NF & 17016 & 3439 \\
\hline DR2 long isoform / NF & 11260 & 1182 \\
SSTR2 / NF & 23954 & 416 \\
SSTR5 / NF & 2407 & 3767 \\
gSP & + & ND \\
\hline
\end{tabular}

DR: dopamine receptor; SSTR: somatostatin receptor; NF: normalization factor; ND: not done.

\section{DISCUSSION}

These two case report illustrate how laboratory and molecular data can be used to predict responsiveness to SA therapy in acromegaly. Considering GH levels at diagnosis, the first patient data are not in accordance to the literature. It has already been demonstrated that patients with higher initial GH concentrations are less likely to normalize IGF-I concentrations during treatment (5). Despite very high initial GH levels, after only 3 and 6 months of octreotide $\mathrm{LAR}^{\circledR}$ therapy, normalization of IGF-I and near normal GH levels $(<2.5 \mathrm{ng} / \mathrm{mL})$ were observed. On the other hand, despite of initial impressive GH reduction under octreotide $\mathrm{LAR}^{\circledR}$, the second patient did not achieve disease biochemical control. On the contrary, raising hormone levels associated with increased tumor volume, regardless of octreotide $\mathrm{LAR}^{\circledR}$ dose titration, determined a second surgical approach. Both patients displayed similar GH suppression during acute test with subcutaneous octreotide. An explanation for dissociation between response, in the acute test and during the long-term therapy with octreotide $\mathrm{LAR}^{\circledR}$, might be that the percentage of GH decrease is used as parameter of responsiveness. On the other hand, the goal during the therapy with octreotide $\mathrm{LAR}^{\circledR}$ is to reach GH below $2.5 \mathrm{ng} / \mathrm{mL}$. Therefore, the patient may have a significant percentage of GH decrease during the acute test and a reduction of GH levels during longterm therapy with octreotide $\operatorname{LAR}^{\circledR}$. However, this decrease may not be sufficient to reach tolerable GH levels $(<2.5 \mathrm{ng} / \mathrm{mL})$. In addition, data regarding acute test with octreotide as a predictor of responsiveness to longterm Octreotide $\mathrm{LAR}^{\circledR}$ is conflicting in the literature. It may be explained by methodological differences among the studies such as acute test protocol and parameter used as positive response during the acute test. Regarding our patients, the distinct biochemical behavior in response to octreotide $\mathrm{LAR}^{\circledR}$ therapy, despite similar initial GH levels and response to acute test, raises the question regarding other factors determining tumor SA sensitivity.

One possible explanation to this discrepancy is the identification of gsp oncogene in patient \#1. Although this analysis was not done in patient \#2, the fact that patient \#l is gsp positive increases her chance to be successfully controlled with octreotide $\mathrm{LAR}^{\circledR}$. In fact, several studies explored SA responsiveness in the light of $g s p$ status and it seems that gsp positive patients are better responders (20-26), although there is some controversy in the literature (18).

Regarding DR and SSTR mRNA profile in both tumors, it is interesting to note that both patients displayed higher SSTR than DR mRNA levels, differently from the previously observed by our group in a larger series of patients. Median DR2 total, DR2 long isoform, SSTR2 and SSTR 5 mRNA expression were 5276, 1709,1316 and 2068 copies, respectively [unpublished data for DR and reference (32) for SSTR]. However, patient \#l had predominant SSTR2 mRNA levels over the other studied receptors and patient \#2 had predominant SSTR5 mRNA levels (Table 2).

Patient \#1 shows a very good response to octreotide $\operatorname{LAR}^{\circledR}$, considering biochemical status and tumor shrinkage as well. It should be stressed that her SSTR2 mRNA levels are 18 times higher than median expression of acromegalic patients in our previous series, which may help to explain, along with gsp status, her impressive octreotide sensitivity. On the other hand, patient \#2 shows a poor response to octreotide $\mathrm{LAR}^{\circledR}$ in terms of biochemical control as well as tumor shrinkage. His SSTR2 mRNA levels are 3 times lower and his SSTR 5 mRNA levels are 1.8 times higher than median expression of acromegalic patients. Somatostatin receptor subtype $5 \mathrm{mRNA}$ levels have already been shown to be predictors of unfavorable response to octreotide LAR $^{\circledR}$ therapy (32). Also, SSTR2/SSTR5 ratio has been previously explored by our group as a predictor of biochemical disease control with octreotide $\mathrm{LAR}^{\circledR}$. A SSTR2/SSTR 5 ratio of 1.3 displayed the best profile with sensitivity $88 \%$ and specificity $92 \%$ (32). In the present cases reported, SSTR2/SSTR5 ratios were 9.95 and 0.11 for patients \#1 and \#2, respectively, justifying the octreotide $\mathrm{LAR}^{\circledast}$ responsiveness observed. 
Internalization phenomenon due to somatostatin exposure was evaluated in vitro, but there is no data regarding that in vivo $(36,37)$. Data from studies that evaluated the long-term efficacy of SA failed in demonstrating the tachyphylaxis effect in acomegaly. In fact, Cozzi and cols. (6) observed sustained suppression of GH/IGF-I hypersecretion throughout the study, without tachyphylaxis in any patient even after four years of continuous treatment. Even if the exposure to octreotide LAR ${ }^{\circledast}$ could affect the SSTR pattern expression, both patients in this study were submitted to octreotide $\mathrm{LAR}^{\circledR}$ before surgery (before collecting the tumor sample), allowing comparison of the receptor expression profile between them.

Finally, exploring the knowledge that DR2 forms heterodimers with SSTR2 and SSTR5 and that the composition of these receptor complexes can alter the response to SA $(38,39)$, it is important to stand out that patient \#1 and \#2 had DR2 mRNA levels 3.2 times higher and 1.5 times lower than median expression of acromegalic tumors, respectively. To support the present observations, a recent report revealed that in vitro response to octreotide was enhanced in adenomas which expressed higher levels of DR2 (40).

In conclusion, these two cases illustrate how molecular analysis of the tumor fragment can predict octreotide LAR $^{\circledR}$ responsiveness, in contrary to biochemical data, which showed conflicting results. Therefore, we suggest the routine analysis of SSTR and DR expression in acromegalic patients who have been operated on.

Disclosure: Mônica Gadelha: Research Principal Investigator, Novartis and Ipsen; Speaker, Novartis and Pfizer; Medical Advisory Board, Pfizer; Leonardo Vieira Neto: Research Co-investigator, Novartis and Ipsen; Giselle F. Taboada: Research Co-investigator, Novartis; no other potencial conflict of interest to this article was reported.

\section{REFERENCES}

1. Melmed S, Casanueva FF, Cavagnini F, Chanson P, Frohman L, Grossman A, et al. Guidelines for acromegaly management. J Clin Endocrinol Metab. 2002;87(9):4054-8.

2. Nomikos P, Buchfelder M, Fahlbusch R. The outcome of surgery in 668 patients with acromegaly using current criteria of biochemical 'cure'. Eur J Endocrinol. 2005;152(3):379-87.

3. Freda PU, Katznelson L, van der Lely AJ, Reyes CM, Zhao S, Rabinowitz D. Long-acting somatostatin analog therapy of acromegaly: a meta-analysis. J Clin Endocrinol Metab. 2005;90(8):4465-73.

4. Mercado M, Borges F, Bouterfa H, Chang TC, Chervin A, Farrall AJ, et al. A prospective, multicentre study to investigate the efficacy, safety and tolerability of octreotide LAR (long-acting repeatable octreotide) in the primary therapy of patients with acromegaly. Clin Endocrinol (Oxf). 2007;66(6):859-68.

5. Newman CB, Melmed S, Snyder PJ, Young WF, Boyajy LD, Levy R, et al. Safety and efficacy of long-term octreotide therapy of acromegaly: results of a multicenter trial in 103 patients--a clinical research center study. J Clin Endocrinol Metab. 1995;80(9):2768-75.

6. Cozzi R, Attanasio R, Montini M, Pagani G, Lasio G, Lodrini S, et al. Four-year treatment with octreotide-long-acting repeatable in 110 acromegalic patients: predictive value of shortterm results? J Clin Endocrinol Metab. 2003;88(7):3090-8.

7. Biermasz NR, Pereira AM, Smit JW, Romijn JA, Roelfsema F. Intravenous octreotide test predicts the long term outcome of treatment with octreotide-long-acting repeatable in active acromegaly. Growth Horm IGF Res. 2005;15(3):200-6.

8. Colao A, Ferone D, Lastoria S, Marzullo P, Cerbone G, Di Sarno $A$, et al. Prediction of efficacy of octreotide therapy in patients with acromegaly. J Clin Endocrinol Metab. 1996;81(6): 2356-62.

9. de Herder WW, Taal HR, Uitterlinden P, Feelders RA, Janssen JA, van der Lely AJ. Limited predictive value of an acute test with subcutaneous octreotide for long-term IGF-I normalization with Sandostatin LAR in acromegaly. Eur J Endocrinol. 2005;153(1):67-71.

10. Halah FP, Elias LL, Martinelli CE, Jr., Castro M, Moreira AC. [Usefulness of subcutaneous or long-acting octreotide as a predictive test and in the treatment of acromegaly]. Arq Bras Endocrinol Metabol. 2004;48(2):245-52.

11. Karavitaki N, Botusan I, Radian S, Coculescu M, Turner HE, Wass JA. The value of an acute octreotide suppression test in predicting long-term responses to depot somatostatin analogues in patients with active acromegaly. Clin Endocrinol (Oxf). 2005;62(3):282-8.

12. Lamberts SW, Uitterlinden P, Schuijff PC, Klijn JG. Therapy of acromegaly with sandostatin: the predictive value of an acute test, the value of serum somatomedin- $C$ measurements in dose adjustment and the definition of a biochemical 'cure'. Clin Endocrinol (Oxf). 1988;29(4):411-20.

13. Lindsay JR, McConnell EM, Hunter SJ, McCance DR, Sheridan $B$, Atkinson AB. Poor responses to a test dose of subcutaneous octreotide predict the need for adjuvant therapy to achieve 'safe' growth hormone levels. Pituitary. 2004;7(3):139-44.

14. Taboada GF, Donangelo I, Guimaraes RF, Silva MO, Fontes R, Gadelha MR. [Acute test with subcutaneous octreotide as a predictor of the response to treatment with octreotide LAR]. Arq Bras Endocrinol Metabol. 2005;49(3):390-5.

15. Legovini P, De Menis E, Billeci D, Conti B, Zoli P, Conte N. 111 Indium-pentetreotide pituitary scintigraphy and hormonal responses to octreotide in acromegalic patients. J Endocrinol Invest. 1997;20(7):424-8.

16. Plockinger U, Bader M, Hopfenmuller W, Saeger W, Quabbe HJ. Results of somatostatin receptor scintigraphy do not predict pituitary tumor volume- and hormone-response to ocreotide therapy and do not correlate with tumor histology. Eur J Endocrinol. 1997;136(4):369-76.

17. Ezzat S, Kontogeorgos G, Redelmeier DA, Horvath E, Harris $A G$, Kovacs K. In vivo responsiveness of morphological variants of growth hormone-producing pituitary adenomas to octreotide. Eur J Endocrinol. 1995;133(6):686-90.

18. Fougner SL, Borota OC, Berg JP, Hald JK, Ramm-Pettersen J, Bollerslev J. The clinical response to somatostatin analogues in acromegaly correlates to the somatostatin receptor subtype 
2a protein expression of the adenoma. Clin Endocrinol (Oxf). 2008;68(3):458-65.

19. Takei M, Suzuki M, Kajiya H, Ishii Y, Tahara S, Miyakoshi T, et al. Immunohistochemical Detection of Somatostatin Receptor (SSTR) Subtypes 2A and 5 in Pituitary Adenoma from Acromegalic Patients: Good Correlation with Preoperative Response to Octreotide. Endocr Pathol. 2007;18(4): 208-16.

20. Barlier A, Gunz G, Zamora AJ, Morange-Ramos I, FigarellaBranger $D$, Dufour $H$, et al. Pronostic and therapeutic consequences of $\mathrm{Gs}$ alpha mutations in somatotroph adenomas. J Clin Endocrinol Metab. 1998;83(5):1604-10.

21. Barlier A, Pellegrini-Bouiller I, Gunz G, Zamora AJ, Jaquet $P$, Enjalbert A. Impact of gsp oncogene on the expression of genes coding for Gsalpha, Pit-1, Gi2alpha, and somatostatin receptor 2 in human somatotroph adenomas: involvement in octreotide sensitivity. J Clin Endocrinol Metab. 1999;84(8):2759-65.

22. Bhayana S, Booth GL, Asa SL, Kovacs K, Ezzat S. The implication of somatotroph adenoma phenotype to somatostatin analog responsiveness in acromegaly. J Clin Endocrinol Metab. 2005;90(11):6290-5.

23. Kim HJ, Kim MS, Park YJ, Kim SW, Park DJ, Park KS, et al. Prevalence of Gs alpha mutations in Korean patients with pituitary adenomas. J Endocrinol. 2001;168(2):221-6.

24. Park C, Yang I, Woo J, Kim S, Kim J, Kim Y, et al. Somatostatin (SRIF) receptor subtype 2 and 5 gene expression in growth hormone-secreting pituitary adenomas: the relationship with endogenous srif activity and response to octreotide. Endocr J. 2004;51(2):227-36.

25. Spada A, Arosio M, Bochicchio D, Bazzoni N, Vallar L, Bassetti $\mathrm{M}$, et al. Clinical, biochemical, and morphological correlates in patients bearing growth hormone-secreting pituitary tumors with or without constitutively active adenylyl cyclase. J Clin Endocrinol Metab. 1990;71(6):1421-6.

26. Yang I, Park S, Ryu M, Woo J, Kim S, Kim J, et al. Characteristics of gsp-positive growth hormone-secreting pituitary tumors in Korean acromegalic patients. Eur J Endocrinol. 1996;134(6):720-6.

27. Corbetta S, Ballare E, Mantovani G, Lania A, Losa M, Di Blasio $A M$, et al. Somatostatin receptor subtype 2 and 5 in human $\mathrm{GH}$-secreting pituitary adenomas: analysis of gene sequence and mRNA expression. Eur J Clin Invest. 2001;31(3):208-14.

28. Hofland LJ, van der Hoek J, van Koetsveld PM, de Herder WW, Waaijers M, Sprij-Mooij D, et al. The novel somatostatin analog SOM230 is a potent inhibitor of hormone release by growth hormone- and prolactin-secreting pituitary adenomas in vitro. J Clin Endocrinol Metab. 2004;89(4):1577-85.

29. Jaquet $P$, Saveanu A, Gunz G, Fina F, Zamora AJ, Grino M, et al. Human somatostatin receptor subtypes in acromegaly: distinct patterns of messenger ribonucleic acid expression and hormone suppression identify different tumoral phenotypes. J Clin Endocrinol Metab. 2000;85(2):781-92.

30. Saveanu A, Gunz G, Dufour H, Caron P, Fina F, Ouafik L, et al. Bim-23244, a somatostatin receptor subtype 2- and 5-selective analog with enhanced efficacy in suppressing growth hormone (GH) from octreotide-resistant human GH-secreting adenomas. J Clin Endocrinol Metab. 2001;86(1):140-5.

31. Taboada GF, Luque RM, Bastos W, Guimaraes RF, Marcondes JB, Chimelli LM, et al. Quantitative analysis of somatostatin receptor subtype (SSTR1-5) gene expression levels in somatotropinomas and non-functioning pituitary adenomas. Eur $\mathrm{J}$ Endocrinol. 2007;156(1):65-74.

32. Taboada GF, Luque RM, Neto LV, Machado Ede O, Sbaffi BC, Domingues RC, et al. Quantitative analysis of somatostatin receptor subtypes (1-5) gene expression levels in somatotropinomas and correlation to in vivo hormonal and tumor volume responses to treatment with octreotide LAR. Eur J Endocrinol. 2008;158(3):295-303.

33. Lundin P, Pedersen F. Volume of pituitary macroadenomas: assessment by MRI. J Comput Assist Tomogr. 1992;16(4):519-28.

34. Vandesompele J, De Preter K, Pattyn F, Poppe B, Van Roy N, De Paepe A, et al. Accurate normalization of real-time quantitative RT-PCR data by geometric averaging of multiple internal control genes. Genome Biol. 2002;18;3(7):RESEARCH0034.

35. Ballare E, Mantovani S, Lania A, Di Blasio AM, Vallar L, Spada A. Activating mutations of the Gs alpha gene are associated with low levels of Gs alpha protein in growth hormone-secreting tumors. J Clin Endocrinol Metab. 1998;83(12):4386-90.

36. Hofland LJ, Lamberts SW. The pathophysiological consequences of somatostatin receptor internalization and resistance. Endocr Rev. 2003;24(1):28-47.

37. Hukovic N, Panetta R, Kumar U, Patel YC. Agonist-dependent regulation of cloned human somatostatin receptor types 1-5 (hSSTR1-5): subtype selective internalization or upregulation. Endocrinology. 1996;137(9):4046-9.

38. Baragli A, Alturaihi $H$, Watt HL, Abdallah A, Kumar U. Heterooligomerization of human dopamine receptor 2 and somatostatin receptor 2 Co-immunoprecipitation and fluorescence resonance energy transfer analysis. Cell Signal. 2007;19(11): 2304-16.

39. Rocheville M, Lange DC, Kumar U, Patel SC, Patel RC, Patel YC. Receptors for dopamine and somatostatin: formation of hetero-oligomers with enhanced functional activity. Science. 2000;288(5463):154-7.

40. Ferone D, de Herder WW, Pivonello R, Kros JM, van Koetsveld PM, de Jong T, et al. Correlation of in vitro and in vivo somatotropic adenoma responsiveness to somatostatin analogs and dopamine agonists with immunohistochemical evaluation of somatostatin and dopamine receptors and electron microscopy. J Clin Endocrinol Metab. 2008;93(4):1412-7.

\section{Correspondence to:}

Mônica R. Gadelha

Rua Nascimento Silva, 555 apt: 101

22421-020 Rio de Janeiro RJ

E-mail: mgadelha@hucff.ufr.br 